\title{
Justice as Responsibility for the Others: A Levinasian Critique on Organizational Justice
}

\author{
GUGLIELMO FALDETTA
}

guglielmo.faldetta@unikore.it

Kore University of Enna

\begin{abstract}
This study aims to investigate how justice can be effective in restoring situations of injustice, particularly when they are caused by damaged or broken relationships in organizations, as inspired by principles of compassion, empathy, or mercy. In particular, we look for a convincing philosophical foundation for justice, proposing Levinas' ethics of responsibility as a way to explain it.

The research question of this study originates from recognizing the importance of the normative dimensions of restoring justice. We argue that a notion of justice inspired by responsibility for the others can promote an organizational climate where people tend to forgive and reconcile each other instead of seeking personal vengeance, which often escalates out of control, creating unproductive conflicts. Justice under a Levinasian approach can bring also better relationships among organizational members, and a general better perception of workplace justice, so positively influencing also the likelihood of resolving workplace conflict.
\end{abstract}

\section{Introduction}

Organizational justice researchers have generally understood justice as a subjective perception (Goldman and Cropanzano, 2015). Even if this view has been useful as justice perceptions have been related to valuable individual and organizational results, it has marginalized the normative dimension of organizational justice (Fortin and Fellenz, 2008). Moreover, understanding justice as a perception has proved to be less effective in repairing injustices or restoring organizational relationships after having experienced injustice.

The research question of this study originates from recognizing the importance of the normative dimensions of restoring justice (Goodstein et al., 2014), and the need for studying deep philosophical issues about it. Moreover, Rynes et al. (2012) have recently highlighted the importance of studying care and compassion as principles to which everyone in organizations must be responsible.

In this sense, this study aims to investigate how justice can be effective in restoring situations of injustice, particularly when they are caused by damaged or broken relationships in organizations, as inspired by principles of compassion, empathy, or mercy. In particular, we look for a convincing philosophical foundation for justice, proposing Levinas' ethics of responsibility as a way to explain it. In this sense, we claim the need of a corporeal and embodied ethics (Hancock, 2008; Pullen and Rhodes, 2014, 2015), which takes form into concrete relations made of care, compassion, and generosity. 
The article is organized as follows. First, it analyses the concept of organizational justice under the traditional approaches, namely distributive, procedural and interactional organizational justice. The second section addresses the issue of a normative approach to organizational justice, starting from deontic justice to introduce the concept of restorative justice. The fourth section presents the ethical foundation of justice under a Levinasian approach; in this sense, it firstly introduce Levinas' ethics or responsibility, and then it presents the Levinasian concept of justice, to finally address the ethical foundation of restorative justice.

\section{The traditional approaches to organizational justice}

According to Van Buren III (2008), organizational justice, although generally connected to organizational efficiency, was a secondary consideration of management scholars writing during the first 65 years of the twentieth century.

In the 1960s a few contributions introduced the notion of distributive justice, or the perceived fairness of outcomes (Adams, 1963), at first through equity theory. In this sense, maybe the earliest theory of distributive justice can be attributed to Aristotle (Gaertner, 1994). In his Nicomachean Ethics, the Greek philosopher presented the classical law of proportions in the form of an equation, as an equality of ratios. In his equity theory, Adams (1963) argued that the outcomes one receives should be proportional to the inputs he contributes.

After distributive justice, the focus shifted to procedural justice, that is the perceived fairness of the procedures used to determine an outcome (Thibaut and Walker, 1975). Procedural justice refers to the means by which outcomes are allocated, but not specifically to the outcomes themselves. Procedural justice establishes certain principles specifying and governing the roles of participants within the decision-making processes. Procedural justice can also be an important part of distributive justice, as perceptions of fair treatment and outcomes depend on the explanations given for those outcomes, not just on the outcome itself.

Bies and Moag (1986) proposed an extension to the concept of procedural justice, in order to identify the interpersonal component of justice. These scholars proposed the notion of interactional justice, which refers to how one person treats another. Research on interactional justice has determined that it can influence employees' trust in management, their affective commitment to the organization, and withdrawal behaviors (Barling and Phillips, 1993).

Interactional justice has conceptually and empirically separated into two dimensions named informational justice and interpersonal justice; the first one refers to explanations and social accounts, while the second one refers to respectful consideration and sensitivity (Colquitt, 2001). Informational justice refers to whether one is truthful and provides adequate justifications when things go badly, while interpersonal justice refers to the respect and dignity with which one treats another.

Organizational justice has been understood to be a mean to an end rather than an end in itself. Studies on organizational justice have traditionally focused on describing and explaining how individuals actually behave in their work lives. This tradition has been termed empirically oriented or descriptive (Cropanzano and Stein, 2009). Organizational 
scholars have been less concerned with what is just and more concerned with what people believe and perceive to be just.

For instance, empirical studies on justice have found that organizational justice is positively related to many organizational outcomes, such as job performance, job satisfaction (Leung et al., 1996), organizational commitment (Viswesvaran and Ones, 2002), organizational citizenship behaviors (Chiaburu and Lim, 2008; Kamdar, McAllister and Turban, 2006), corporate stakeholder responsibility (Husted, 1998; Sachs and Maurer, 2009), perceived organizational support (Ambrose and Schminke, 2003), antisocial work behavior (Thau, Aquino and Wittek, 2007) and turnover intentions (Kim, 2009).

Another important finding about the outcomes of organizational justice is that employees' perceptions about the fairness of the treatment they receive from their organizations can influence their decisions about engaging in morally proscribed behaviors, such as workplace deviance, or in highly regarded behaviors, like citizenship behaviors, that substantially exceed moral minimums (Zoghbi-Manriqe-de-Lara, 2010).

A last outcome of organizational justice that has been individuated by empirical studies is social relationships, particularly those with supervisors (Masterson et al., 2000). It seems that employees' procedural justice perceptions affect reactions toward organizations, while interactional justice perceptions affect reactions toward supervisors. Social relationships are very important for organizational justice perceptions, as they can be also considered as antecedents, particularly for interactional justice (Umphress et al., 2003). Justice perceptions are not formed in isolation; rather, they are subject to the influence of those with whom individuals interact. People who regularly interact with each other are more likely to have similar perceptions than people who do not interact.

\section{From deontic justice to restorative justice}

Organizational justice researchers have rarely asked philosophical or critical questions about the implications of justice considerations on organizational reality. While outcomes of perceived justice have been the focus of a larger body of research in organizations, the proactive creation of justice has received little attention (Fortin and Fellenz, 2008). The traditional approaches to organizational justice generally assume an individualistic and rationally self-interested approach to fairness, as they consider how individuals come to perceive whether or not they themselves are treated fairly (Cropanzano, Goldman and Folger, 2003). Moreover, as it has been shown above, the research on organizational justice has often been addressed to identify its positive outcomes for organizations. In this sense, as Fortin and Fellenz (2008) have pointed out, the ideological basis adopted by the organizational justice field is pro-management rather than employee-centered. The interactional dimension of organizational justice seems to be a sort of relational corrective to the utilitarian and contractarian side of justice that characterizes the first two dimensions. However, this is not enough to investigate how fair others are treated, or what is a just behavior for a broader community.

According to a normative and prescriptive approach, we may develop and use philosophical theories to prescribe what justice must be (Cropanzano and Stein, 2009; Cugueró-Escofet and Fortin, 2014). This school of thought has contributed to overcome the study of organizational justice as an instrumentally motivated behavior towards a broader 
consideration of the philosophical basis of organizational justice (Cropanzano et al. 2001; Folger, 2001).

From a normative point of view, some scholars have proposed the notion of deontic justice. This is a notion of justice for justice's sake, where individuals are motivated by a sense of duty, obligation, and moral virtue (Cropanzano et al., 2003; Rupp and Bell, 2010). Deontic justice is based on Kantian ethics, that consists of the presence of categorical imperatives or $a$ priori universal ethical principles, which guide individual's cognitive processes and behaviors. According to Rupp and Bell (2010), deontic justice acts as a process where an individual feels a sense of moral distress when he sees others being treated unfairly, so creating a desire to see the transgressors accountable for their moral wrong, or even a reaction against the perpetrator in order to restore a state of justice.

Compared to the traditional approaches, this theory gives a normative basis to justice, by founding on Kantian ethics; most of all, it considers justice as a process rather than an individual perception, so making it a useful tool for regulating behaviors in cases of injustice. In this sense, deontic justice applies not only to the victim or the perpetrator, but also to third parties who are not connected nor identified with them.

Deontic justice seems to provide a good theory to solve problems of justice when many parties are involved (the victim, the offender, third parties who mediate between them, or other parties who can be interested as stakeholders). As deontic justice is based on Kantian ethics, it finds its philosophical justification on individual moral reasoning, which follows universal categorical imperatives. Being a purely formally deduced ethical system, it lacks any references to love, empathy, compassion, or any other human emotions associated with ethics.

For the purpose of this article, we argue that deontic justice $s$ is too dependent on individual moral reasoning and on the implementation of rules and procedures inspired by it. Deontic justice risks being far from real life, where people in flesh and bones face injustice with their concrete body. Seeking justice in in order to heal interpersonal relationships asks for a corporeal and embodied ethics (Faldetta, 2015; Pullen and Rhodes, 2014, 2015), that is made of concrete relations made of care, compassion, and generosity.

Another way to overcome the individualistic approach to organizational justice is researching on how justice might be in order to benefit other people. For instance, a stream of research is about third-party reactions to injustice (De Cremer and Van Hiél, 2006; O'reilly and Aquino, 2011), which considers how fairly individuals perceive others to be treated. In this sense, some authors note that the notion of justice includes also treating others as they should or deserve to be treated by adhering to standards of right and wrong (Cropanzano et al., 2003).

Another important stream of research is about restorative justice. According to Braithwaite (1999: 5), restorative justice is "a process whereby all the parties with a stake in a particular offense come together to resolve collectively how to deal with the aftermath of the offense and its implications for the future". Research on restorative justice has prevalently come from the field of criminal justice and conflict resolution, and in practice typically takes the form of a mediation between the criminal offenders and all of the affected parties (Presser and Gardner, 2000; Wenzel et al., 2008). 
Restorative justice is different from other forms of justice because it primarily focuses on justice for all with respect to how the victim, the offender, and other stakeholders involved (also the organization) collectively are committed to restore justice. By establishing a process where these three actors are all involved in restoring justice, restorative justice goes beyond the other notions of justice which primarily focus on assisting the victim or punishing transgressors. By adopting a restorative justice perspective, the focus shifts from the violation of norms (legal, social or moral) to the violation of relationships between people (Goodstein and Aquino, 2010).

Restorative justice does not aim to punish, particularly in a retributive sense, it is always forward-looking, aiming at restoring and reconciling the offender, the victim and the other parties involved (Bertels, Cody and Pek, 2014).

Restorative justice may be effective if both the offender and the victim act coherently. "In other words, reintegration is more likely when the offender has offered amends and the victim has acknowledged those amends and extended forgiveness" (Goodstein and Butterfield, 2010: 462). What is important is that all the actors involved in the process have a certain moral development or identity (Aquino and Reed, 2002). So offenders, victims, and other stakeholders within the organization should have a set of moral values that may promote feelings of love and compassion.

In order to find a philosophical basis to this kind of justice, we argue that we have to look for a notion of justice based on the concept of responsibility towards the others, as Levinas' philosophy is.

\section{A Levinasian approach to justice}

This section is organized as follows. First, it briefly introduces Levinas' philosophy, particularly focusing on his ethics of responsibility. Second, it analyses how Levinas passes from ethics to justice, extending the relationship between the subject and the Other through the appearance of the third. Third, it analyses the concept of restorative justice starting from a Levinasian notion of justice.

\section{Levinas and the ethics of responsibility}

Before analyzing Levinas' concept of justice, we briefly introduce Levinas' ethics of responsibility, which justice is based on. Levinas did not suggest any new ethical theories, nor he gave any normative recommendations. His interest was rather directed towards understanding how a call for responsibility is experienced, that is how the subject receives this call and how and to what extent it is transformed into something manageable (Aasland, 2007).

For Levinas (1981), man 'is' responsibility even before being intentionality. The primary foundation of a Levinasian ethics is in 'being for the Other'; ethics is not founded on 'being', as a reason, or thought, or choice, it is beyond essence, that is that a priori, from the start, the Other affects us despite ourselves (Levinas, 1981).

According to Levinas, the relation with the other is not controlled or managed by the subject. As Jones (2003: 227) claims, "I could recognize the Other but still view the Other as 
essentially the same as me, sharing my needs, desires and passions", but this kind of response would only reassure my self-certainty as an isolated subject. For Levinas, responsibility is not altruism or benevolence, but an unconditional obsession with the Other. Responsibility does not begin in the subject, in his consciousness, but it always originates from the call of the Other.

The relationship with the Other is asymmetric, and it can't wait for reciprocity, so it expects nothing in return. If the subject sought reciprocity, than he would be moved by his own interest, and he would enter into the realm of calculation of its own advantage, thinking of himself rather than the Other.

Moreover, the relation with the Other can't be managed by rules or norms. For Levinas, it would be impossible to teach someone to have a relation of responsibility toward the other. According to Levinas (1972), any conception based on principles inspired by general rules, codes and procedures, and operated by a means-end rational calculus, is not ethical. The call for responsibility is beyond what is manageable; by the moment I try to manage it, I will reduce it into a normative theory within my own universe of understanding in which I am at the center. Procedures that try to manage the relationships with the Other reduce the Other to someone expected by the manager, thus violating Levinas' approach (Karamali, 2007).

This kind of responsibility could seem motivated by a sense of duty, like a Kantian categorical imperative; or it could seem that the Levinasian subject is not free to choose, as he was imprisoned in the cage of responsibility. For Levinas, responsibility is not a matter of choice, but it comes before intentionality and will. There is no subject able of generosity, compassion, or love, in the sense that there is no need of a constituted subject to have responsibility; on the contrary, the subject is constituted by responsibility.

Levinas ethics is different from Kantian ethics because its key concept, that is responsibility, is something that rests with a specific subject, which he cannot pass to or share with anyone else. So responsibility is not generalizable because it is corporeal and embodied, and cannot be used to deduce universal moral norms. In this sense, Levinas has little to say about concrete moral duties, he cannot make general claims about what people have to do.

For Levinas, responsibility is a matter of sensibility, proximity, humanity; it is a form of exposure to the Other. It seizes people in flesh and bones, bodies that can be hurt and suffering.

The problem of this absolute unilateral responsibility might be that it could imply a solipsistic and isolated ethics. As we said before, for Levinas reciprocity is linked to a contractual view; the expectation of the other's ethical commitment would contaminate the pure gratuity of the subject's responsibility. But, as Levinas argues, this doesn't preclude the other's responsibility; the fact that the subject should not expect the Other to treat him as his or her other, nevertheless implies that the Other approaches the subject with the same ethical solicitude. It is a sort of reciprocal asymmetry (Tatransky, 2008): when the Other receives something, this awakes not an obligation to give something in return, but a feeling of gratitude, which can move the Other, but from within, to reciprocate. So the Other's choice to reciprocate is an autonomous act, an expression of his self-determination.

Reciprocal asymmetry is what can make Levinasian ethics or responsibility concrete in social relations, as it is the case of justice in organizations. Every subject is endlessly 
responsible towards the Others, he is permanently in debt, but this condition affects everyone, making the original asymmetry of Levinasian responsibility reciprocal.

\section{The subject, the Other and the third: from ethics to justice}

The above described ethical relationship is between a subject and the Other. This kind of relationship is problematized by the appearance of the third, that is another Other for the subject, but also an Other for the Other. The endless and timeless obligation that each of us have towards the Others becomes somehow limited by the incalculable being and claim of the other Other, that is the third persons (Byers and Rhodes, 2007; Faldetta, 2016).

The arrival of the third puts the subject in a complex situation, where he has to face two Others to be compared. In terms of Levinasian ethics, the choice between two Others is impossible, since not only the subject is in relation with two Others, but the two Others are in turn in relation to each other. So the subject can not take an infinite responsibility for one of the Other he faces, because this would mean to make violence against the excluded Other.

Both the Other and the third are neighbors to the subject, there is no asymmetry: the arrival of the third lets the subject enter in a wider sociality, between equals, while ethics concerns the asymmetrical relationship, between a subject who has to obey to an Other.

As Aasland (2007) claims, it is necessary to compare and to prioritize between several Others, and the subject is responsible also for how he compares and prioritizes. This is, according to Levinas, how ethics is put into practice, not through normative rules or recommendations, but as a sense of awareness of, and an interest in, the concept of justice and how this can be managed.

In this sense, justice is a characteristic of the relationship between the subject and the third, where the infinite responsibility for the Other is limited by multiple responsibilities towards the others. On the one hand, justice marks the limit of the ethical relationship; on the other hand, justice forces the subject to consider all its responsibilities, and in this sense it can be meant as an extension and an enlargement of responsibility.

The relation between responsibility and justice is very complex; even if justice takes meaning from responsibility, justice and responsibility bring mutual contradictions. The subject is responsible, and he lives his responsibility for this and for all the other Others. Although justice leads him to shift attention elsewhere, he is always responsible for the Other he faces.

Justice interrupts the infinite responsibility for the Other, it lets the subject turn his back on the Other he faces. On the other hand, responsibility is a precondition for justice, delegitimizing this walking away from the Other. Justice is the need to compare the incomparable, and it is therefore a violence against the Other. To act justly, the responsible subject has to violate asymmetry, treating the Other not as the ultimate authority, but as an individual whose rights can be measured and calculated (Burggraeve, 2002).

The appearance of the third makes responsibility divided: it is no longer the infinite concern for the Other, but it is directed also towards the responsibility that the Other has towards another Other, that is the third. The Other and the third oblige the subject simultaneously; so he has to be fair in distributing his attention, and he has to compare, calculate, and evaluate. 
For Levinas, justice does not imply a degraded or insufficient responsibility. In justice, responsibility remains infinite, but the answer that the subject gives to the Other is limited by other Others. Justice then is a sort of remedy to the blindness of the infinite answer to the Other, which runs the risk of not considering the third, who is also a neighbour. In this sense, justice is a realization of responsibility.

Justice is impossible if the subject is not inspired by the ethical call to responsibility. For Levinas, justice, as other political institutions, takes root in the ethical relationships, so avoiding degenerating in a mere technique of social equilibrium. Being the task of justice is to establish social harmony among individuals, it has to depart from the absolute responsibility for the Others instead of on cold legal requirements.

Founding justice on responsibility, Levinas combines justice with love, compassion and mercy, showing that these dimensions are related to each other. So Levinasian ethics of responsibility is not a vacuum, an abstract absolute that is unattainable by the subject, but is the foundation of all the social institutions, as it is justice.

\section{Restorative justice under a Levinasian approach}

We have seen that restorative justice focuses on justice for all, with respect to how the victim, the offender, and other stakeholders involved collectively are committed to repair damaged relationships. We have seen also that restorative justice is a process where all the parties should act inspired by love, compassion, and mercy. From what has been said about Levinas' ethics and his concept of justice, we can deduce that this philosophical approach may provide a convincing foundation for restorative justice.

In this sense, restorative justice has to be connected to the relationships between individuals, which are folded back to the asymmetry of the subjective experience of the faceto-face. Restorative justice has not to be meant in an instrumental sense, as a mean to satisfy individual interests (of the victim, of the offender, or of the organization). In a Levinasian sense, restorative justice is 'Other-oriented', so that every actor involved in the process acts for the Others.

When a victim forgives his offender, he is not forgetting, he is acting upon the past, repeating the event and purifying it (Levinas, 1969). In this sense, "the past is not represented in the present through memory, or nullified through forgetting, but repeated in the past. Furthermore, the past event is repeated, but repeated differently, as if it has not passed, as if it never happened, as if the doer had not 'committed' herself in action" (Allers, 2011: 175).

This point can go against common practice of ethics in the context of organizations, when business ethics is practiced through sets of rules, codes, or administrative procedures (Roberts, 2003). As Byers and Rhodes (2007: 241) claim, "whereas such systems might make a claim to ethics, where they begin and end in rationally applied principles, they are, in a Levinasian sense, not in any way ethical".

In this sense, justice cannot be administered through codes of conduct, statements of values, or bureaucratic procedures that claim, if followed, to guarantee or predict ethics trying to make objective what is subjective or, better, relational. Following a Levinasian approach, restorative justice could be developed through the continual review and re-articulation of 
what is experienced in on-going relationships between the members of the organization. If someone asked if an individual is doing what is just, there would be no definitive answer, this would swing between yes and no, in a perpetually unresolved ambivalence.

As stated by Bevan and Corvellec (2007: 213), "it makes little difference whether one elects some special virtues to cardinal managerial virtue, compiles a set of rules for good conduct, sets up procedures to satisfy one's own interest or designs an algorithm to assess the consequences of corporate action on one's stakeholders. Virtues, rules, self-interest or principles are all reductions, reasoned expressions of values, judgemental categories, preferences or modes of understanding that are egologically specific to whoever enunciates them".

\section{Conclusion}

In this article we have proposed a philosophical foundation for restorative justice, inspired by Levinas' ethics of responsibility.

Restorative justice under a Levinasian approach can promote an organizational climate where people tend to forgive and reconcile each other instead of seeking personal vengeance, which often escalates out of control, creating unproductive conflicts (Aquino et al., 2003; Aquino, Tripp and Bies, 2006). Restorative justice can bring also better relationships among organizational members, and a general better perception of workplace justice, so positively influencing also the likelihood of resolving workplace conflict (Goodstein and Aquino, 2010).

Adopting a Levinasian ethics requires a corporeal and embodied responsibility in organizations, which can be practiced only by individuals who hold themselves open to the reality of an infinite and endless responsibility towards the other (Baker and Roberts, 2011; Faldetta, 2015). The need for a corporeal and embodied ethics (Hancock, 2008; Pullen and Rhodes, 2014, 2015) takes form into concrete relations made of care, compassion, generosity, and any forms of feeling experienced pre-reflexively through the body.

The adoption of a corporeal and embodied ethics can facilitate putting into practice such values as compassion, mercy, or love, which are crucial in a process of repairing and restoring damaged relationships.

\section{Keywords}

Justice; responsibility; Levinas; organization; ethics.

\section{Reference list}

Aasland, D.G. (2007) "The exteriority of ethics in management and its transition into justice: A Levinasian approach to ethics in business", Business Ethics: A European Review, 16: 220226.

Adams, J.S. (1963) "Toward an understanding of inequity", Journal of Abnormal and Social Psychology, 67: 422-436. 
Allers, C.R. (2011) “Undoing what has been done: Hannah Arendt and Emmanuel Levinas on forgiveness", In Forgiveness. Promise, possibility \& failure, G. Karabin, K. Wigura (eds), pp. 171-181, Freeland, UK: Inter-Disciplinary Press.

Ambrose, M.L., Schminke, M. (2003) “Organizational structure as a moderator of the relationship between procedural justice, interactional justice, perceived organizational support, and supervisory trust", Journal of Applied Psychology, 88: 295-305.

Aquino, K., Grover, S.L., Goldman, B. and Folger, R. (2003) “When push doesn't come to shove: Interpersonal forgiveness in workplace relationships", Journal of Management Inquiry, 12: 209-216.

Aquino, K., Reed, A. II (2002) "The self-importance of moral identity", Journal of Personality and Social Psychology, 83: 1423-1440.

Aquino, K., Tripp, T.M., Bies, R.J. (2006) “Getting even or moving on? Power, procedural justice, and types of offense as predictors of revenge, forgiveness, reconciliation, and avoidance in organizations", Journal of Applied Psychology, 91: 653-668.

Baker, M., Roberts, J. (2011) "All in the mind? Ethical identity and the allure of corporate responsibility", Journal of Business Ethics, 101: 5-15.

Barling, J., Phillips, M. (1993) "Interactional, formal, and distributive justice in the workplace: an exploratory study", The Journal of Psychology, 127: 649-656.

Bertels, S., Cody, M., Pek, S. (2014) “A responsive approach to organizational misconduct: Rehabilitation, reintegration, and the reduction of re-offense", Business Ethics Quarterly, 24: 343-370.

Bevan, D., Corvellec, H. (2007) "The impossibility of corporate ethics: for a Levinasian approach to managerial ethics", Business Ethics: A European Review, 16: 208-219.

Bies, R.J., Moag, J.S. (1986) "Interactional justice: Communication criteria for fairness", In Research on Negotiation in Organizations Vol. 1, R.J. Lewicki, B.H. Sheppard, M.H. Bazerman (eds), pp. 43-55, Greenwich, CT: JAI Press.

Braithwaite, J. (1999) "Restorative justice: Assessing optimistic and pessimistic accounts", Crime and Justice, 25: 1-127.

Burggraeve, R. (2002) The Wisdom of Love in the Service of Love: Emmanuel Levinas on Justice, Peace and Human Rights, Milwaukee, WI: Marquette University Press.

Byers, D., Rhodes, C. (2007) “Ethics, alterity, and organizational justice”, Business Ethics: A European Review, 16: 239-250.

Chiaburu, D.S., Lim, A.S. (2008) "Manager trustworthiness or interactional justice? Predicting organizational citizenship behavior", Journal of Business Ethics, 83: 453-467.

Colquitt, J.A. (2001) “On the dimensionality of organizational justice: A construct validation of a measure", Journal of Applied Psychology, 86: 386-400.

Cropanzano, R., Byrne, Z., Bobocel, D. and Rupp, D. (2001) "Moral virtues, fairness heuristics, social entities, and other denizens of organizational justice", Journal of Vocational Behavior, 58: 164-209. 
Cropanzano, R., Goldman, B., Folger, R. (2003) “Deontic justice: the role of moral principles in workplace fairness", Journal of Organizational Behavior, 24: 1919-1024.

Cropanzano, R., Stein, J.H. (2009) “Organizational justice and behavioral ethics: Promises and prospects", Business Ethics Quarterly, 19: 193-233.

Cugueró-Escofet, N., Fortin, M. (2014) “One justice or two? A model of reconciliation of normative justice theories and empirical research on organizational justice", Journal of Business Ethics, 124(3): 435-451.

De Cremer, D., Van Hiél, A. (2006) “Effects of another person's fair treatment on one's own emotions and behaviors: The moderating role of how much other cares for you", Organizational Behavior and Human Decision Processes, 100: 231-249.

Faldetta, G. (2015) "A relational approach to responsibility in organizations: The logic of gift and Levinasian ethics for a 'corporeal' responsibility", Culture and Organization, Epub ahead of print 21 December 2015. DOI: 10.1080/14759551.2015.1122600.

Faldetta, G. (2016) “Organizational caring and organizational justice: Some implications for the employment relationship", International Journal of Organizational Analysis, 24: 64-80.

Folger, R. (2001) "Fairness as deonance", In Research in social issues in management, S.W. Gilliland, D.D. Steiner, D.P. Skarlicki (eds), pp. 3-31, Greenwich, CT: Information Age.

Fortin, M., Fellenz, M.R. (2008) "Hypocrisies of fairness: Towards a more reflexive ethical base in organizational justice research and practice", Journal of Business Ethics, 78: 415-433.

Gaertner, W. (1994) "Distributive justice: Theoretical foundations and empirical findings", European Economic Review, 38: 711-720.

Goldman, B., Cropanzano, R. (2015) "“Justice" and "fairness" are not the same thing", Journal of Organizational Behavior, 36 (2): 313-318.

Goodstein, J., Aquino, K. (2010) “And restorative justice for all: Redemption, forgiveness, and reintegration in organizations", Journal of Organizational Behavior, 31: 624-628.

Goodstein, J., Butterfield, K.D. (2010) “Extending the horizon of business ethics: Restorative justice and the aftermath of unethical behavior", Business Ethics Quarterly, 20: 453-480.

Goodstein, J., Butterfield, K.D., Pfarrer, M.D. and Wicks, A.C. (2014) "Individual and organizational reintegration after ethical or legal transgressions: challenges and opportunities", Business Ethics Quarterly, 24: 315-342.

Hancock, P. (2008) "Embodied generosity and an ethics of organization", Organization Studies, 29: 1357-1373.

Husted, B.W. (1998) "Organizational justice and the management of stakeholder relations", Journal of Business Ethics, 17: 643-651.

Jones, C. (2003) "As if business ethics were possible, 'within such limits'...", Organization, 10: 223-248.

Kamdar, D., McAllister, D.J., Turban, D.B. (2006) “All in a day's work: How follower individual differences and justice perceptions predict $\mathrm{OCB}$ role definitions and behavior", Journal of Applied Psychology, 91: 841-855. 
Karamali, E. (2007) "Has the guest arrived yet? Emmanuel Levinas, a stranger in business ethics", Business Ethics: A European Review, 16: 313-331.

Kim, H. (2009) "Examining the role of informational justice in the wake of downsizing from an organizational relationship management perspective", Journal of Business Ethics, 88: 297-312.

Leung, K., Smith, P.B., Wang, Z. and Sun, H. (1996) "Job satisfaction in joint venture hotels in China: An organizational justice analysis", Journal of International Business Studies, 27: 947962.

Levinas, E. (1969) Totality and infinity: An essay on exteriority, Pittsburgh: Duquesne University Press.

Levinas, E. (1972) Humanisme de l'autre home, Saint-Clement-la-Riviere, France: Fata Morgana.

Levinas, E. (1981) Otherwise than being or beyond essence, New York: Springer Science \& Business Media.

Masterson, S.S., Lewis, K., Goldman, B.M. and Taylor, M.S. (2000) “Integrating justice and social exchange: The differing effects of fair procedures and treatment on work relationships", Academy of Management Journal, 43: 738-748.

O’Reilly, J., Aquino, K. (2011) “A model of third parties' morally motivated responses to mistreatment in organizations", Academy of Management Review, 36: 526-543.

Presser, L., Gaarder, E. (2000) “Can restorative justice reduce battering? Some preliminary considerations", Social Justice, 27 (1): 175-195.

Pullen, A., Rhodes, C. (2014) "Corporeal ethics and the politics of resistance in organizations", Organization, 21: 782-796.

Pullen, A., Rhodes, C. (2015) “Ethics, embodiment and organizations", Organization, 22: 159165.

Roberts, J. (2003) “The manufacture of corporate social responsibility: Constructing corporate sensibility", Organization, 10: 249-265.

Rynes, S.L., Bartunek, J.M., Dutton, J.E. and Margolis, J.D. (2012) “Care and compassion through an organizational lens: Opening up new possibilities", Academy of Management Review, 37: 503-523.

Rupp, D.E., Bell, C.M. (2010) “Extending the deontic model of justice: Moral self-regulation in third-party responses to injustice", Business Ethics Quarterly, 20: 89-106.

Sachs, S., Maurer, M. (2009) "Toward dynamic corporate stakeholder responsibility", Journal of Business Ethics, 85: 535-544.

Tatransky, T. (2008) “A reciprocal asymmetry? Levinas's ethics reconsidered", Ethical Perspectives, 15: 293-307.

Thau, S., Aquino, K., Wittek, R. (2007) “An extension of uncertainty management theory to the self: The relationship between justice, social comparison orientation, and antisocial work behaviors", Journal of Applied Psychology, 92: 250-258.

Thibaut, J., Walker, L. (1975) Procedural justice: A psychological analysis, Hillsdale, NJ: Lawrence Erlbaum Associates. 
Umphress, E.E., Labianca, G., Brass, D.J., Kass, E. and Scholten, L. (2003) "The role of instrumental and expressive social ties in employees' perceptions of organizational justice", Organization Science, 14: 738-753.

Van Buren III, H.J. (2008) "Fairness and the main management theories of the twentieth century: A historical review, 1900-1965", Journal of Business Ethics, 82: 633-644.

Viswesvaran, C., Ones, D.S. (2002) "Examining the construct of organizational justice: A meta-analytic evaluation of relations with work attitudes and behaviors", Journal of Business Ethics, 38: 193-203.

Wenzel, M., Okimoto, T.G., Feather, N.T. and Platow, M.J. (2008) "Retributive and restorative justice", Law and Human Behavior, 32: 375-389.

Zoghbi-Manriqe-de-Lara, P. (2010) “Do unfair procedures predict employees' ethical behavior by deactivating formal regulations?", Journal of Business Ethics, 94: 411-425. 